Michalina KMieciK

Uniwersytet Jagielloński*

iD https://orcid.org/0000-0003-0118-3657

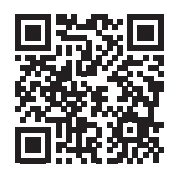

\title{
Paradoksy awangardowego zaangażowania. Milczenie artysty i rewolucja. Przypadek Aleksandra Wata
}

Paradoxes of the Avant-Garde Engagement. Silence and Revolution. The Case of Aleksander Wat

\begin{abstract}
At the end of the 1920s Aleksander Wat quits publishing his literary texts and focuses on editorial and journalistic activity thus developing the model of a romantic "rigorist of action" created by Adam Mickiewicz. The purpose of this article is, first of all, to compare the ideological postulates of Mickiewicz and Wat regarding the relationship between language and action, as well as to demonstrate the convergence of their social and political background. Secondly - I will examine the journalistic activity of Wat from the period of "Miesięcznik Literacki" (1929-1930): analyze his critique of Futurism (as too "literary" and only apparently engaged) and a new formula of non-fiction (presented in essays devoted to the social role of reportage).
\end{abstract}


* Katedra Teorii Literatury Uniwersytetu Jagiellońskiego ul. Golębia 16, p. 41, 31-007 Kraków e-mail:michalina.kmiecik@uj.edu.pl

Tekst powstał w ramach projektu Style zachowań awangardowych (program Sonata 10, nr rej. 2015/19/D/HS2/01003) finansowanego przez Narodowe Centrum Nauki. 
pergaminy i papiery zastępują naszą skórę

[Michel de Certeau, Ekonomia piśmienna]

W jaki sposób rewolucyjny gest mógłby realnie kształtować literaturę? Przybierałby zapewne postać literatury agitacyjnej, tendencyjnej, propagandowej: rewolucja dokonywałaby się zatem w treści, pozostając przy formie wyjątkowo konserwatywnej. Przykładem tego typu działania na polu awangardowym byłaby sztuka produktywistyczna, dzieje radzieckiego konstruktywizmu, zwrot ku literaturze proletariackiej, a następnie socrealistycznej (więcej na ten temat — zob. Groys 1992). Inną strategią wydaje się radykalizm formalny, polegający na performatywizacji słowa i literatury. Od lat dziesiątych dwudziestego wieku na arenę dziejów na szeroką skalę wkraczają manifesty ze swoją wyrazistą poetyką, przechwytywaną następnie przez same teksty artystyczne/poetyckie (zob. Puchner 2006). Poezja staje się intermedialnym projektem, wykorzystuje obraz, dźwięk czy teatralizację, aby wydobyć odbiorcę z jego strefy komunikacyjnego komfortu. Ten rodzaj „upolitycznienia” literatury (rozumiany w duchu myśli filozoficznej Jacquesa Rancière’a - zob. Rancière 2007) polega więc na stopniowym poszerzaniu pola ludzkiej świadomości i społecznej wrażliwości, rewolucjonizowaniu jego sposobu myślenia oraz życia codziennego. Istnieje jednak droga trzecia, radykalizująca wnioski wypływające z tej wskazywanej powyżej. Skoro bowiem zadaniem literatury staje się działanie, aktywizacja mas, zerwanie z autonomią komunikacji artystycznej, jej ostatecznym celem okazywałaby się autonegacja. Jak pisał Theodor W. Adorno w Teorii estetycznej:

To, że sztuka musi dzisiaj poddawać się refleksji, znaczy tyle, że staje się świadoma swoich idiosynkrazji, że je artykułuje. W konsekwencji sztuka reaguje alergicznie na siebie samą; sumarycznym efektem określonej negacji, której dokonuje, jest negacja samej siebie. (Adorno 1994: 67-68)

Negatywna siła myślenia awangardowego przekreśla granicę między słowem a czynem, a w obliczu realnie rozgrywającej się rewolucji społecznej czy politycznej wybiera milczenie jako strategię najbardziej wobec niej adekwatną. Odrzucający literackość i pozorność literatury pisarze stają się tym samym faktycznymi aktantami, uczestnikami realności: rezygnują z literatury rozumianej jako pozór, ale nie z języka rozumianego jako bezpośredni komunikat. 
Odrzucają zatem poezję, zbliżając się do publicystyki czy literatury faktu. Milczący awangardziści okazują się potomkami romantycznych „rygorystów czynu”: na polu literatury polskiej zatem — nieodrodnymi spadkobiercami późnej myśli Adama Mickiewicza. Szczególnie interesujący pozostaje zaś ich stosunek do pisma (który nie jest, rzecz jasna, prostą negacją); wycofując się z literatury, nie wycofują się bowiem z piśmiennictwa. Domagają się za to niewątpliwie redefinicji jego rozumienia.

Jak słusznie odnotowuje Michel de Certeau, pismo pracuje na rzecz postępu, a więc może wchodzić w rozliczne relacje z przestrzenią władzy i polityki (de Certeau 2006: 606). Jednocześnie, stanowi wykwit władzy już istniejącej, ustanowionej i obowiązującej; przeciwko niemu właśnie występuje subwersywna, gwałtowna i rozregulowana „mowa rewolucji”, której gorączka i zapalczywość budują nowy porządek, jaki dopiero zostanie przekuty w porządek pisma (nowej litery nowego prawa). Pismo reprezentujące status quo koncentruje się — zgodnie z ideą de Certeau - wokół trzech podstawowych wyobrażeń: białej kartki, tekstu oraz gry piśmiennej. Pusta strona, ustanawiająca gest tworzenia dzieła literackiego, to „przestrzeń «własna» wyznaczająca miejsce produkcji dla podmiotu. [...] Ustanawia ono wycofanie się oraz dystans podmiotu wobec określonej sfery czynności” (de Certeau 2006: 606). Pismo zakłada więc konieczność istnienia jednostkowego podmiotu, który stanie się wytwórcą dzieła funkcjonującego w granicach kartki, niewykraczającego poza nią, nierezygnującego z własnej autonomii. Wytwarza się w ten sposób zamknięte „pole własnego działania”, które nie wchodzi w kolizję z rzeczywistością: "Jest to gest kartezjański wprowadzający w y c ię ci e [podkr. - M.K.], za pomocą którego ustanowione zostaje, wraz z miejscem dla pisma, panowanie (oraz izolacja) podmiotu nad p r zed mi o te m" (de Certeau 2006: 606). Kategoria wycięcia, jaką posługuje się francuski badacz, zasługuje na szczególną uwagę. Papier staje się tutaj izolatorem: oddziela czlowieka od świata, podmiot mówiący od przedmiotu, o którym się mówi, ideę wyrażoną w słowach od czynnego uczestnictwa. „Pergaminy i papiery” zaczynają wypierać jednostkę rozumianą jako psychofizyczna realność — odcieleśniają. Ich związek z pismem oraz tekstem (progresywnymi, nowoczesnymi, będącymi wytworami postępowego myślenia) daje jednak szansę dokonania subwersywnego odwrócenia: tekst może zostać zapisany na ludzkiej skórze, może odcisnąć się na niej nie jako „ciąg wyartykułowanych operacji” (de Certeau 2006: 606), ale jako doświadczenie. W miejsce pergaminów zastępujących naszą skórę pojawić się powinna skóra zastępująca pergamin. Tym samym pismo można ocalić jedynie za cenę odchodzenia od tekstu rozumianego jako wyprodukowany, logiczny artefakt oraz jako ekspresja indywidualnego „ja”. Pismo rewolucyjne domaga się podwójnego przekroczenia: zarówno zerwania z „piśmienną grą" oderwaną od realnych praktyk społecznych (zob. de Certeau 2006: 607), jak i z prymatem artystycznej jednostkowości. Poszukiwania w „strefie krzyku" (de Certeau 2006: 621) prowadzą do - jak określał to Adam Mickiewicz — zatarcia swojej osobowości (zob. Mickiewicz 1998: 12): „choćbym musiał na koniec krzyczeć, nie cofnę się przed krzykiem. Krzyki te nie dobywają się z mej osobowości, tę gotówem poświęcić; krzyki te wydzierają się z głębi ducha wielkiego ludu" (Mickiewicz 1998: 11).

Prezentacja strategii awangardowego, rewolucyjnego milczenia zaczynać się zatem musi od wykonania ruchu ku przeszłości: ku romantycznej tradycji zerwania ze sztuką w imię czynu, gdyż „tylko życiem zaświadczając rzeczywistość życia [...] będę mógł liczyć na wasze współodczuwanie" (Mickiewicz 1998: 11-12). Kiedy główny bohater tego artykułu, Aleksander Wat, decyduje się zawiesić pisanie (stopniowo odchodzi najpierw od poezji, publikuje w roku 1926 [z datą 1927] tom opowiadań Bezrobotny Lucyfer, by następnie skupić się na 
działalności redaktorskiej w lewicowym „Miesięczniku Literackim”), powtarza znany z dziejów polskiej literatury gest Adama Mickiewicza. Przemyślenie zależności między twórczością a zaangażowaniem, pisaniem i rewolucją prowadzi go do odrzucenia indywidualnej pracy artystycznej, oddania "papieru i pergaminu” ${ }^{1}$. Rewolucja zapisać się musi na skórze: w jego przypadku zresztą zapis ten wyryje się na niej już na zawsze, będzie niemożliwy do zapomnienia. W końcówce lat dwudziestych Wat jednak jeszcze nie wie, w jaki sposób „ucieleśni” się jego mariaż z komunizmem; aby pozostać prawdziwym i wiarygodnym, decyduje się więc wkroczyć na drogę wyznaczoną i przetartą przez Mickiewicza.

\section{„Rygoryści czynu”: Mickiewicz i Wat}

Alina Witkowska, charakteryzując stosunek Mickiewicza do kwestii rewolucji w kanonicznym już opracowaniu poświęconym politycznemu zaangażowaniu poety - książce Mickiewicz. Stowo i czyn - nazywa go nie bez powodu „rygorystą czynu” (Witkowska 1975: 274). Określenie to odnosi przede wszystkim do jego poglądów na relację między językiem (a więc tekstem publicystycznym lub literackim) oraz działaniem (politycznym bądź społecznym).

Zamilknięcie Mickiewicza nie bez powodu splata się z jego pracą wykładowcy oraz zaangażowaniem w działalność Koła Sprawy Bożej, a następnie poświęceniem się publicystyce w „Trybunie Ludów”. I choć należy pamiętać, że poezja wieszcza wygasa stopniowo w okresie lozańskim, wydaje się, że to właśnie rozczarowanie słowem i potrzeba pełnego, czynnego zaangażowania stoją za rezygnacją Mickiewicza z publikowania literatury ${ }^{2}$. Jak słusznie zauważa Ewa Hoffmann-Piotrowska, „tworzenie poezji było dla niego drogą ujawniania prawdy” (2004: 67), sposobem nie tyle jej komunikowania, ile uobecniania, formą „bycia-w-świecie”. Pismo miało zbliżyć to, co jednostkowe, do narodu, stać się zarzewiem nowych sposobów myślenia oraz wspólnotowego funkcjonowania. Jego fantastyczna teoria słowa jako czynu otwiera drogę ku przełamaniu granicy między sztuką a życiem.

Mickiewicz rozpoczyna jej prezentację od ważnego stwierdzenia: „Ręczyć słowem — w języku ludu — znaczy ręczyć samym sobą" (1998: 77). Słowo nie stanowi cienia ani powtórzenia (naśladowania) myśli: jest jej materialną formą, niezbywalnym elementem. Kiedy posługujemy się słowem, musimy brać za nie pełną odpowiedzialność, traktować je jak przedłużenie własnego ciała. Poeta pisze o tym wprost w wykładzie XII, kiedy prezentuje tezę o nowym barbarzyńcy: „słowo to człowiek; wyrazy 'słowo' i 'człowiek' mają u Słowian jedno pochodzenie” (Mickiewicz 1998: 149). Stanowi ono zatem esencję (w sensie: materializację) idei:

Czujemy, jak w gębi naszego jestestwa zapala się jakiś ogień wewnętrzny; ogień ten przenika i pochłania całą naszą organizację, roztapia ją, że tak powiem, a wtedy duch wydobywa z naszej tak roztopionej organizacji ekstrakt, esencję i z niej tworzy tę świetlistą i lotną kulę, którą zowiemy

1 Kwestia „milczenia Mickiewicza” była oczywiście szeroko i bardzo różnie komentowana: poczynając od klasycznego już tekstu Wiktora Weintrauba Dlaczego Mickiewicz przestat pisać? (opublikowanego w tomie Mickiewicz - mistyczny polityk $i$ inne studia o poecie - Weintraub 1998: 100-107) po rozpoznania Jarosława Marka Rymkiewicza, Ewy Hoffmann-Piotrowskiej, Krzysztofa Rutkowskiego czy Mikołaja Sokołowskiego. Konflikt między wyjaśnieniami biograficznymi, uwzględniającymi problemy małżeńskie i bytowe poety a tymi skupionymi wokół teorii o przekreśleniu granicy między słowem a czynem streszcza Aleksander Nawarecki w książce Maty Mickiewicz. Studia mikrologiczne (Nawarecki 2003: 78-106). W swoim tekście przyjmuję raczej - za Aliną Witkowską i Krzysztofem Rutkowskim - tezę o pogłębiającym się zaangażowania artysty i jego przejściu na stronę „poetyki działania”. Ona właśnie pozwala zobaczyć w Mickiewiczu prekursora stylów zachowań awangardowych.

2 Na temat pierwszych wzmianek o krytyce pisma w „Pielgrzymie Polskim” zob. Przychodniak 2001: 223-235. 
słowem; opuszcza nas ona, choć się od nas nie odrywa, znika, a jednak trwa tak długo, jak duch, co ją wydał, to znaczy jest niezniszczalna.

Słowo więc to ciało i duch stopione razem ogniem boskim przebywającym w człowieku. (Mickiewicz 1998: 78)

Nie istnieje rozdział między ciałem i duchem, słowem i myślą: stanowią one rewers i awers tej samej monety. Podobnie, początkowo, dzieje się ze słowem i działaniem. Nie bez powodu Mickiewicz posługuje się obrazem płonącej kuli - słowo okazuje się zarzewiem gestu, akcji ${ }^{3}$. Wyobrażamy je sobie jako coś trzymanego w dłoniach, co - choć wyrzucamy to w przestrzeń - wciąż pozostaje częścią nas samych, splecione świetlistym promieniem z naszym wnętrzem. To nasze ciało daje bowiem słowu „tajny popęd” (Mickiewicz 1998: 79), siłę kreacji i niszczenia. Zatem, aby odnaleźć słowo prawdziwe, „żywe”, należy zajrzeć w głąb siebie, z siebie wydobyć twórczy ogień. Jak jednak pogodzić tę wizję z prezentowaną już w pierwszym wykładzie kursu czwartego tezą o konieczności zacierania swojej osobowości i „zapominania o sobie" (Mickiewicz 1998: 12)?

Adam Sikora słusznie odnotowuje w swojej książce poświęconej myśli politycznej Hoene-Wrońskiego, Towiańskiego i Mickiewicza, że rozczarowanie zinstytucjonalizowaną religią oraz filozofią, a także niechęć względem doktrynerstwa prowadzą Mickiewicza z jednej strony do zaufania temu, co najgłębiej pojedyncze, z drugiej zaś - wyrzeczenia się własnej osobowości rozumianej jako spójny, logiczny konstrukt. Wiara żywa, która pomaga stać się częścią wspólnoty, historii, odrzucić spetryfikowane formy instytucjonalne, wymaga

głębokiego aktu pokory, radykalnego „zaparcia się siebie”, „ofiary” z własnej osobowości, poświęcenia, które staje się rzeczywistą abnegacją celów własnych ludzkiego indywiduum, rezygnacji więc ze wszystkiego, co jednostkowe i partykularne, co człowieka oddziela od innych ludzi i sobie ich przeciwstawia. (Sikora 1967: 279)

Wyzwolenie się od doktrynerstwa jest możliwe tylko za sprawą "porywu ducha” (Mickiewicz 1998: 22), który domaga się „porzucenia wszystkiego”. Wychodząc z „ja”, wydobywa się on zatem z ograniczeń indywidualnej świadomości, która popycha go w stronę egoizmu, rozpływa się natomiast w tożsamości zbiorowej, dociera do powszechności. Jak słusznie podsumowuje Sikora:

Żyć życiem prawdziwym to egzystować przez wspólnotę, we wspólnocie i dla wspólnoty, poświęcając jej wszystko, cokolwiek się posiada. Takie zaś przekonanie musiało znosić wiarę we własną misję, osobistą wyjątkowość i wielkość. (Sikora 1967: 280)

Przynależność okazuje się matrycą wlaną w duszę, która czeka na swoją materializację i realizację. Wspólnotowość zaś od początku istnienia zostaje przez człowieka intymnie zinterioryzowana. Paradoks Mickiewiczowski zakłada zatem, że w punkcie wyjścia każdy z nas jest wewnętrznie podwojony: posiada w środku zarówno dążenia jednostkowe, jak i wspólnotowe, dochodzi zaś do pojednania z powszechnością poprzez destrukcję tego, co własne. Jego zadaniem staje się — jak to później sentencjonalnie zdefiniuje Wat — „obciosać się, uschnąć,

3 Co ciekawe, aby powstało, organizacja wewnętrzna człowieka, jego ustrukturowana tożsamość, musi zostać „roztopiona”, zdekonstruowana. 
wyżąć” (Wiersze somatyczne, Wat 2008: 125), zdobyć się na „totalne «ogołocenie się», «wyzucie się ze wszystkiego, co swoje», całkowite opróżnienie pamięci” (Walicki 1970: 59)4.

Aporetyczny pogląd Mickiewicza manifestuje się także na innym poziomie: rezygnacja z podmiotowości (rozumianej jako spójna tożsamość potwierdzona w tekście artystycznym) okazuje się jedynym gwarantem jej integralności. Dlatego właśnie od lat trzydziestych poeta rezygnuje z literatury na rzecz publicystyki oraz działalności publicznej. W wykładzie IX pada słynne już stwierdzenie:

Kiedy intencja i siła połączą się z sobą w jednym duchu, staje się to czynem dokonanym. Człowiek tak działający jest prawdziwym autorem. U Rzymian auctor oznacza człowieka, który sp raw ia, pod którego kierunkiem rzecz jakaś została w y ko n a n a, nie zaś napisana, i który w ten sposób pomnaża, auget, zasób rzeczy wykonanych. Ta właśnie realizacja daje jednocześnie człowiekowi powagę, prawdziwą powagę.

[...] w prawdach moralnych każde słowo zobowiązuje, każde słowo zniewala. [...] cokolwiek kto głosi, cokolwiek podaje, ma obowiązek realizować i prędzej czy później będzie wystawiony na próbę, aby się okazało, czy miał zamiar i siłę wprowadzić to w czyn. (Mickiewicz 1998: 106-107, podkr. autora)

Autor to już nie pisarz, człowiek utrwalający swoje myśli czy idee. To raczej działacz, performer, natchniony. Jego celem przestaje być produkcja słów (tekstu artystycznego), których nie sposób zakorzenić w rzeczywistym doświadczeniu. Zadaniem jest reforma widzialnego, wprowadzenie nowych praktyk, prezentacja faktycznego stanu i wyciąganie z niego wniosków. Każdy komunikat musi być (niczym w Mickiewiczowskiej teorii języka) „zrośnięty” z wysyłającą go ręką; świetlista kula słowa nigdy tak naprawdę nie odrywa się od kształtujących ją ducha i ciała.

Absolutne spojenie słowa i czynu prowadzi jednak - tak jak ujmuje to Peter Bürger w swojej słynnej Teorii awangardy - do likwidacji sztuki. Zaczyna ona sobie stawiać za cel już nie wytworzenie artefaktu (nawet takiego o charakterze subwersywnym), ale zorganizowanie nowej praktyki życiowej (Bürger 2006: 62). Przekonanie o konieczności „wcielenia” literatury w życie kończy się zatem śmiercią samej literatury. Aleksander Wat w Moim wieku stwierdza wprost:

Rzeczywiście myślałem, że w szczęśliwym społeczeństwie komunistycznym nie będzie literatury, tak jak nie będzie filozofii. Bo jednak czułem, zdawałem sobie sprawę, że literatura jest związana z tym, co w człowieku jest najmniej uspołecznione, antyspołeczne i irracjonalne. Uważałem to za tragiczne, ale uważałem, że takie jest jądro literatury. A ludzkość trzeba zbudować racjonalnie. [...] Wybrałem to, co Szkłowski, co grupa LEF-u: nie literatura, ale fakt i propaganda. (Wat 1990: 150)

Ta dość katastroficzna konstatacja Wata zdaje się nie przylegać do cytowanych wcześniej, pełnych pasji ustępów z Mickiewicza. Wieszcz nie postrzega swojego posłannictwa jako racjonalnego - wręcz przeciwnie, jego myśl polityczna ma podłoże religijne. Nie bez powodu Wiktor Weintraub nazywa go „mistycznym politykiem” (1998). Żarliwość Mickiewicza uzupełnia jednak rozważania Wata: obaj wierzą w konieczność poświęcenia jednostkowego losu na rzecz wspólnoty, obaj odrzucają literaturę przede wszystkim jako skażoną egotyzmem,

4 Walicki przywołuje tu fragment wypowiedzi Mickiewicza z relacji Aleksandra Chodźki: „Dlatego trzeba się wyzuć ze wszystkiego, co swoje, wypróżnić, inaczej bowiem nie przyjmiesz" (Adama Mickiewicza wspomnienia i myśli 1958: 327). 
idiosynkratycznością i próżnością. Poszukują słowa, które wyzbędzie się „prywatnej” sygnatury i zastąpi ją śladem ducha (rozumianego jako coś ponadindywidualnego, reprezentującego interes grupy/klasy/narodu). Wat dochodzi jednak do przekonania, że wszystko, co pisze (a - podobnie jak Mickiewicz — pisze, choć nie publikuje ${ }^{5}$ ), pogrąża się w oparach irracjonalizmu, czczej estetyzacji, skrajnej idiomatyczności. Pozostaje zatem nie do przyjęcia i jako takie sprawia, że literatura „jest w ogóle niemożliwa” (Wat 1990: 150-151) ${ }^{6}$. Na łamach „Miesięcznika Literackiego” publikuje zatem twórczość agitacyjną Broniewskiego (choć przyznaje, że jej nie rozumie i nie akceptuje z poetologicznego, estetycznego punktu widzenia) - swoje teksty zaś „autocenzuruje” i odkłada do szuflady. Skoro bowiem jego przekonania estetyczne nie mogą zostać uzgodnione z duchem czasu i dziejową koniecznością, pisanie musi ulec radykalnej transformacji: poezja znika, proza zmienia się w reportaż i esej. Miłoszowi wyznaje: „optymizm społeczny łączył się u mnie z pesymizmem poetyckim” (Wat 1990: 151), a dalej mówi wręcz o „katastrofizmie estetycznym” wynikającym z przekonania, iż nie sposób pogodzić szczęścia ludzkości ze szczęściem poezji.

W słowach Wata pobrzmiewa przekonanie o konieczności całkowitej rewolucji: totalnego przeobrażenia rzeczywistości i jej przewartościowania. To, co dotychczas traktowaliśmy jako punkt dojścia i doskonalenia się ludzkości (w duchu filozofii Heglowskiej), staje się raczej punktem startowym: słowo, samopoznanie poprzez literaturę (szczególnie autoanalityczną, oniryczną literaturę, jaką był na przykład Watowski Piecyk) prowadzić ma do oczyszczenia się z własnej, niepełnej (zawsze podwojonej, zawodnej) podmiotowości i osiągnięcia stanu, w którym weźmiemy odpowiedzialność za wspólnotę. Mickiewicz i Wat nie tyle więc porzucają słowo, ile czynią je auctorem, samą poezję zwracają zaś jej greckim źródłom: czynieniu, działaniu. Autor Mojego wieku wyobraża sobie słowo jako przedłużenie ręki mówiącego, obiekt użyteczny. Zbliża się tym samym do metafory „świetlistej kuli” używanej przez Mickiewicza w Prelekcjach paryskich: odpowiednio ukształtowane, nasączone esencją rewolucyjną słowo może stać się materiałem wybuchowym, punktem zapalnym.

Negacji podlega przede wszystkim „słowo książkowe” i sama idea książki jako nośnika. Jak słusznie odnotowuje Aleksander Nawarecki w odniesieniu do Mickiewicza:

Nie dostrzegał w niej atrybutu sztuki słowa, nie idealizował, lecz traktował jak rzecz, machinę do przekazu informacji; urządzenie przestarzałe, coraz bardziej zawodny środek porozumienia między ludźmi. Dlatego pod koniec życia mógł powiedzieć do Antoine’a Dessus — „drogi przyjacielu, przeminął czas książek". (Nawarecki 2003: 91)

„Książkowość” oznaczała też dla niego zakrzepnięcie myśli, jej kanonizację. W Prelekcjach wielokrotnie powraca zagadnienie antydogmatyzmu (zob. wykład II w IV kursie Prelekcji paryskich - Mickiewicz 1998: 14-23) i odwrotu od książkowego uniwersum: zwrócenia się w stronę człowieka ${ }^{7}$. W pewnym momencie nawołuje on wręcz (a wątek ten podejmą na początku XX wieku, choć o wiele bardziej radykalnie, futuryści): „Nikt nie będzie podkładał

5 Zob. Wat 1990: 150. Badacze twórczości Mickiewicza także zwracają uwagę na to, że milczenie poety było pozorne: nie publikował swoich tekstów, ale wciąż próbował pisać (zob. Hoffmann-Piotrowska 2004: 65).

6 Podobne poglądy wyrażał - zgodnie ze świadectwem Aleksandra Chodźki — sam Mickiewicz (zob. Hoffmann-Piotrowska 2004: 72).

7 Zob. wykład III w czwartym kursie Prelekcji paryskich: „nie przychodziliśmy tu, opierając się jedynie na książkach i rękopisach; wzięliśmy za tekst człowieka, a książki za komentarz” oraz wykład X: „strząsnąć jak pył 
ognia pod biblioteki, ale miejmy nadzieję, że ludzie będą mniej do nich uczęszczać, kiedy życie publiczne stanie się bardziej pouczające” (Mickiewicz 1998: 158). Książka jako uporządkowany logicznie wywód kłóci się z wyobrażeniem „mowy żywej”, przeciwstawia się radykalnie oralności: staje się synonimem definiowanej przez de Certeau kultury pisma, która włącza autorów w obręb piśmiennej gry władzy oraz podporządkowania ${ }^{8}$. Zarówno Mickiewicz, jak i Wat w jej miejsce próbują podstawić inny rodzaj piśmienności (bo nie zapominajmy, że nie milczą oni zupełnie; piszą, co więcej, publikują artykuły) — nawiązujący do praktyk mowy, gorączkowo poszukujący „nowego słowa”, nowych formuł działania artystycznego i politycznego.

\section{Reportaż jako gatunek odnowicielski}

Mickiewicz zwraca się zatem ku pracy redaktorskiej, decyduje się skupić na działalności publicystycznej, ponieważ poszukuje nowych możliwości użycia i uobecnienia pisma, które wyrwą się jednocześnie z podtrzymującej polityczne status quo "gry piśmiennej”. Pragnie innego stylu, innego języka, opartego na zasadach właściwych oralności - tezy te podtrzyma zresztą i zradykalizuje w działalności z lat czterdziestych. Jak bowiem odnotowuje Mikołaj Sokołowski: „słowo oralne jest spoiwem świata, gwarantem łączności sfer, nieba i ziemi, czynnikiem zapewniającym powrót kultury pierwotnie mówionej, w której zjawisko tragizmu nie istnieje” (Sokołowski 1998: 164). Czasopismo polityczne (najpierw „Pielgrzym Polski”, a następnie „Trybuna Ludów”) umożliwia mu poszukiwanie formuły „słowa-działania”, które będzie zakorzenione „w bezpośrednim doświadczeniu życiowym” (Przychodniak 2001: 226).

Podobnie Wat - decyduje się odejść od literatury wyrażającej się poprzez medium książki i zwrócić ku temu, co efemeryczne i sfragmentaryzowane, aktualne, posiadające „datę ważności” (kolejne numery czasopisma wypierają przecież poprzednie). Czasopiśmiennictwo obarczone jest bowiem swoistą tymczasowością, progresywnością, rozwija się w czasie i reaguje na przemiany rzeczywistości zewnętrznej. Choć — jako zanurzone w kulturze pisma wciąż bierze udział w piśmiennej ekonomii, uczestniczy w niej już na innych zasadach, za cel obierając sobie przewartościowanie dotychczas obowiązujących prawideł, wprowadzenie nowych jakości w przestrzeń dyskursu, negowanie rozpropagowanych przez oponentów idei, subwersywność. Dodatkowo Wat w swoich artykułach z „Miesięcznika Literackiego” skupia się na apologii gatunku, który miałby szansę najpełniej realizować założenia „nowego piśmiennictwa” - na reportażu. Jak zauważa w artykule Reportaż jako rodzaj literacki, literatura faktu rozwija się głównie w prasie i przeżywa swój rozkwit dzięki gazetowej technologii:

dopiero technika robienia gazety nadała reportażowi jego dzisiejszą formę — krótkiego, zwięzłego, efektownego przedstawienia faktów. Ale bardziej niż technika gazetowa wpływają na ukształtowanie reportażu te potrzeby polityczne, które powołują do życia, organizują i orjentują samą prasę. (Wat 1930d: 331-332)

z szaty wszelkie więzy łączące nas ze światem martwym, ze światem książek, światem systematów; otworzyć duszę naszą, abyśmy raz odetchnęli jako ludzie swobodni” (Mickiewicz 1998: 32, 131-132).

8 Ten wątek w myśli towianistycznej i refleksji samego Mickiewicza podejmuje Krzysztof Rutkowski, analizując twórczość Edwarda Stachury. Pisze: „Człowiek książkowy nie może ani napotkać, ani odkryć prawdy, ponieważ działa tylko częściowo za pomocą dwóch zmysłów: wzroku i słuchu. Człowiek żywy nie musi być wykształcony" (Rutkowski 1984: 189). 
Z jednej strony, istotna wydaje się sama forma narzucona przez „czasopiśmienność” reportażu: ograniczona ilość miejsca w druku, popularny charakter, który wymaga rezygnacji z elitarystycznego przeintelektualizowania, założenie, iż czytelnik „konsumuje” magazyn dość szybko, często w pośpiechu i miejscu publicznym. Z drugiej zaś - publikowanie w czasopiśmie o określonym zapleczu ideologiczno-światopoglądowym obliguje autora do przyjmowania jasnej perspektywy klasowej, społecznej, politycznej. „Orientacja” staje się kwestią palącą i kluczową; nie domaga się jednak wprowadzania do samego tekstu elementów agitacyjno-propagandowych. Wat konkluduje: „Reportaż uczy się wyrażać myśl polityczną w samem podawaniu faktów, w ich doborze, w montażu, obywając się bez omawiających komentarzy" (Wat 1930d: 332). Literatura tendencyjna i propagandowa nie jest dla Wata ideałem twórczości rewolucyjnej; w tym miejscu znów zdaje się on spotykać z Mickiewiczem. Chodzi o takie kształtowanie języka i stylu, które uczyni go jak najbardziej przezroczystym zarówno pod względem ideologicznym, jak i indywidualnym: autor reportażu koncentruje się na montażu faktów (przefiltrowanych przez jego świadomość i usytuowanie klasowe, ale nie prywatne), a nie ich komentowaniu, interpretowaniu czy światopoglądowym podbarwianiu. Chodzi o pisanie, które stanie się niesfingowanym świadectwem konkretnych doświadczeń:

Reportaż dzisiejszy utwierdził się jako samoistny rodzaj, zasadza się nie na impresji lecz dokładnej obserwacji i wywiadzie, nie potrzebuje ozdoby i garnituru, jego artystyczną legitymacją jest właśnie ścisłość i dokumentarność. (Wat 1930d: 332)

Reportaż tym będzie różnił się od powieści zaangażowanej i w tym będzie ją przewyższał: rezygnując z „wymysłu”, uniknie pozoru autentyczności (diagnozowanego przez Wata z przekąsem w tzw. niemieckiej powieści pacyfistycznej, szczególnie u E.M. Remarque’a — zob. Wat 1929: 23) i kształtowania „przeżyć «literackiemi» sposobami” (Wat 1929: 23). Antyliterackość, aestetyczność, skupienie na faktografii, styl skrótowy, dziennikarski, surowy staną się najważniejszymi wyznacznikami twórczości reportażowej. „Grzeczne, porcelanowe figurki” (Wat 1929: 29) z powieści zaangażowanej zostaną zastąpione opisem realnych postaci z krwi i kości, które opowiedzą o swoich doświadczeniach swoimi słowami: jako korespondenci robotniczy lub bohaterowie wywiadów zbieranych przez reportażystę.

Dla Wata nie jest istotne, kto - człowiek o jakim zapleczu intelektualno-kulturowym zostanie autorem. Dlatego w 1930 roku ogłasza w „Miesięczniku Literackim” konkurs na reportaż. W komunikacie pisze wprost, iż nie jest on adresowany do zawodowych literatów:

Warunkiem dobrego reportażu jest umiejętność ścisłego obserwowania rzeczy, faktów, wypadków i stosunków - widzenia zorganizowanego przez świadomą ideę polityczno-socjalną, która wyraża się w samym sposobie widzenia zjawisk obserwowanych, w doborze i układzie obserwacyj.

(Ogtoszenie konkursu na reportaż 1930: 329)

Nie chodzi o teksty o wysokich walorach artystycznych, ale o wnikliwą obserwację rzeczywistości, która uczyni opisywany przedmiot niejako „obecnym”, możliwym do odczucia; musimy mieć wrażenie, że jest on wart naszego uczestnictwa, starań, zainteresowania. Reportaż ma bowiem bardzo ważne zadanie ideologiczne: Wat chce, aby służył umasowieniu sztuki i literatury, a także rozpropagowaniu sprawy proletariackiej. W Jeszcze o reportażu wskazuje trzy warunki popularyzacji literatury: udostępnienie jej masom w przystępnej i zrozumiałej formie; wyrażanie w niej dążeń ideologicznych mas; masowe rozpowszechnienie (Wat 1930a: 
425). Obserwując recepcję „Miesięcznika”, zauważa, że stoi on wciąż po stronie intelektualizmu, nieprzejrzystości językowej, jest dla klasy robotniczej trudny w odbiorze; obowiązujące w nim standardy literackie są zaś zbyt wysokie i — dla poetów proletariackich — właściwie nieosiągalne. Prowadzi go to do przekonania, że sztuka wysokoartystyczna nie jest po prostu w państwie komunistycznym potrzebna, że stanowi wykwit mieszczańskiego pragnienia konsumowania piękna. Reportaż natomiast neguje konieczność współpracy z profesjonalnymi pisarzami; pozwala rozwijać się twórczym potrzebom narodu, dopuszcza do głosu te warstwy społeczne, które dotychczas były spychane na kulturowy margines:

\footnotetext{
Wyjście z wąskiej cechowości zawodowych pisarzy, wywołanie szerokiego dopływu piszących z pośród proletarjatu miejskiego i wiejskiego jest koniecznym warunkiem literatury umasowionej, proletarjackiej. (Wat 1930a: 425)
}

Skoro jednak oddaje się głos bystrym obserwatorom i uczestnikom opisywanych zdarzeń, zasadność funkcjonowania tzw. profesjonalnych literatów zostaje zakwestionowana. Wat sam nie widzi już dla siebie miejsca na scenie literackiej. Nie jest aktywnym działaczem politycznym, nie reprezentuje klasy robotniczej: jego działalność musi ograniczyć się zatem do prac organizacyjnych, redaktorskich — podtrzymywania i stymulowania ekonomii kulturowej. Wytwarzana przez niego sztuka nie posiada bowiem cechy najistotniejszej: nie jest skuteczna.

\section{Nieskuteczność futuryzmu: nakaz milczenia}

W „Miesięczniku Literackim” bardzo mocno wybrzmiewa teza o konieczności i słuszności prowadzenia badań nad literaturą z perspektywy socjologicznej. Zarówno Wat, jak i Andrzej Stawar właśnie w ten sposób najchętniej analizują zjawiska artystyczne. Widać to szczególnie w tekstach Stawara poświęconych Mickiewiczowi, kiedy — na przykład recenzując Bronzowników (sic!) Boya Żeleńskiego — konkluduje: „Rzeczywista analiza różnostronnej działalności Mickiewicza jest poprostu niezbędna dla zrozumienia historji społecznej Polski w wieku XIX” (Stawar 1930a: 215). Interesuje go raczej działalność niż teksty, zwraca także baczną uwagę na socjologiczne uwarunkowania konkretnych rozwiązań artystycznych, kształtowania fabuł czy bohaterów (Stawar 1930b: 300-310).

Podobnie Wat - w powieści pacyfistycznej zajmuje go przede wszystkim rynkowy i ideologiczny wymiar tego rodzaju twórczości. Aby poprawnie rozpoznać znaczenie powieści pacyfistycznej w Niemczech, musimy sięgnąć poza sam tekst, zwrócić się ku warunkującym go kontekstom społecznym oraz politycznym. Wat dowodzi, iż sama literatura służy w tym przypadku określonej krucjacie światopoglądowej (choć pisarze sprytnie ukrywają to pod płaszczykiem „apolityczności”):

Hasła rewolucyjne klasy robotniczej przerabiają się w ideologicznych laboratorjach drobnomieszczańskich na toksyny kontrrewolucji; na aktywny antymilitaryzm proletarjatu mieszczaństwo odpowiada biernym, wykrętnym pacyfizmem, dwuznacznym frazesem pacyfistycznym, który doskonale nadaje się do zamaskowania dzisiejszego neoimperializmu mieszczańskiego, i budowy pancerników [...]. Przy obecnym zaostrzeniu się konfliktów socjalnych, frazes pacyfistyczny może odegrać bardzo ważną rolę i dlatego nie tylko nie natrafia na zakaz „zgóry”, ale wręcz przeciwnie jest nawet, w określonym kierunku, hodowany. (Wat 1930a: 22) 
Wat-publicysta nie interesuje się zatem walorami stylistycznymi czy kompozycyjnymi ze względu na ich wartość estetyczną — analizuje Remarque’a, aby udowodnić jego regresywny i społecznie szkodliwy charakter. Już sam marksistowski język, którym chętnie się posługuje, świadczy o przyjęciu optyki socjologicznej. Podobnie zresztą będzie próbował zanalizować swoje własne doświadczenia literackiego debiutanta w tekstach wspomnieniowych poświęconych futuryzmowi.

Najlepiej jego socjologiczne zacięcie ujawnia się w eseju Wspomnienie of futuryzmie publikowanym w drugim numerze „Miesięcznika”. Na początku stawia mocną tezę o społecznym zapotrzebowaniu na nową, postępową literaturę - za pierwszą wysuniętą propozycję uważa twórczość poetycką Skamandrytów. Deprecjonuje ją jednak jako typowo mieszczańską i nastawioną na szybką, bezrefleksyjną konsumpcję (pozbawioną zatem jakiegokolwiek elementu subwersywnego, politycznego). Bezprogramowość i bezideowość grupy Skamandra interpretuje jako próbę „zajęcia stanowiska poezji oficjalnej” (Wat 1930e: 69), a więc wpisania się w obowiązujące "piśmienne” status quo.

Futuryzm - w tym ujęciu — miałby zatem szansę stać się sztuką prawdziwie rewolucyjną. Żywioł gwałtownego sprzeciwu, w którym jest zanurzony, wydaje się idealną pożywką dla rozwoju myśli politycznie wywrotowej. Co istotne, futuryści mają poczucie, że budują światy poetyckie zupełnie od nowa; tworzą nowe konfiguracje estetyczne i afektywne. Biorą też aktywny udział w przeobrażaniu wizji codziennego życia społeczeństwa. Dla Wata klasycznym przykładem „wojującego futurysty” jest oczywiście Włodzimierz Majakowski, którego poezja „była laboratorjum wybuchów, rozłupujących świat widzialny i pokazujących go w zupełnie nowych kształtach” (Wat 1930c: 282). Zaangażowanie Majakowskiego w jego okresie futurystycznym nie polegało na bezpośredniej politycznej agitacji (tego samego rodzaju aktywności Wat będzie bezskutecznie wypatrywał u polskich kolegów), ale na tworzeniu sztuki masowej, przeznaczonej do performatywnego odtworzenia w przestrzeniach publicznych, zmieniającej smak oraz przyzwyczajenia poznawcze ogółu. Była to liryka obliczona na „usta rozdarte do krzyku” (Wat 1930c: 283-284): wpisująca się zatem idealnie w Mickiewiczowskie wyobrażenie literatury wydobywającej się z rozżarzonej magmy ducha. Niestety, Wat nie odnajduje tego rodzaju żarliwości w twórczości warszawskich i krakowskich „neofuturów”; nie widzi jej też we własnych pierwocinach:

Futuryzm polski chwytał falę regresywną — jego protagoniści wyobrażali sobie, że jest wybitnie antymieszczański - tylko przepuszczal ją przez głośnik dysonansowy i groteskowy. Był krzywym zwierciadłem, w którym Kaliban przyglądał się sobie z grymasem obrzydzenia. (Wat 1930e: 71)

Wat nie dostrzegał ani u siebie, ani u kolegów żadnego przeświadczenia o głębokim związku sztuki z rzeczywistością; ideał Majakowskiego jako "poety rewolucyjnej ulicy” (Wat 1930c: 284), wymierzającego policzek powszechnemu smakowi, był czysto teoretyczny. Nawet jeśli młodzi odwoływali się do rezerwuaru futurystycznych, skandalizujących i bulwersujących opinię publiczną gestów (Wat wspomina w swoim tekście wiele z ich przygód ${ }^{9}$ ), robili to jedynie pour épater le bourgeois, czyli nie bardzo wykraczając poza ideologiczne zaplecze wysokomodernistycznej bohemy. Nie zdawali sobie sprawy z politycznej użyteczności owych gestów; nie przygotowywali w ten sposób żadnego rewolucyjnego gruntu ani świadomo-

9 O skandalizujących występach polskich futurystów zob. Jaworkki 2015. 
ściowej przemiany społeczeństwa. Futuryzm polski Wat diagnozuje jako zabawę młokosów, „wyżywanie się emocjonalności paseistycznej” (Wat 1930e: 72). Być może dlatego tak wiele zauważa w nim elementów dadaistycznych i prymitywistycznych. W jego własnych tekstach dominuje zaś surrealistyczne wypaczenie (Piecyk) czy estetyczna gra pejzażem dźwiękowym (namopaniki). I choć teksty futurystyczne z perspektywy lat trzydziestych poddają się zdaniem redaktora „Miesięcznika” lekturze „ekonomicznej” ${ }^{10}$, ich własne zaplecze ideologiczne pozostaje do bólu mieszczańskie, antyrewolucyjne. Wat podsumowuje:

Wbudowaliśmy się w wyimaginowaną współczesność, sformowaną ze zniekształconych programowo składników, przeważnie importowanych. Społeczeństwo - to byli znajomi i publiczka, zbierająca się na wieczorach, reszta to — abstrakcyjnie, w kalkomanji literackiej widziani burżuje i robotnicy — „cuchnąca uskrzydlona gawiedź”. (Wat 1930e: 72-73)

Dopiero w okresie publikowania „Almanachu Nowej Sztuki” (czyli od 1924 roku) futuryści - głównie za sprawą pogłębienia kontaktów z kręgiem konstruktywistycznym Tadeusza Peipera - zaczynają uwzględniać w swojej działalności kwestie cywilizatorskie, urbanistyczne, technicystyczne. Podobnie jednak jak próby samego „papieża awangardy” mają one "charakter laboratoryjny i sekciarski” (Wat 1930b: 123). Wat często i chętnie używa właśnie metafory „laboratorium” na opisanie poczynań Nowej Sztuki: wyraża ona idealnie jej eksperymentalny charakter, jednak podkreśla też wymiar czysto teoretyczny. Awangarda nie wychodzi w jego odczytaniu poza fazę odizolowanych od rzeczywistości prób, nie ma realnego wpływu na świat czy społeczeństwo, jej oddziaływanie jest zerowe, a wykonywane gesty jawią się jako „sztuka dla sztuki”. Bürgerowskie przejście od autonomii do praktyki życiowej nie następuje - ani u samych futurystów, ani u wieszczących ich upadek konstruktywistów. Jak słusznie notuje Wat: „papierową motyką grzebano u nas futuryzm. Futuryści polscy nie umieli jej wytrącić przeciwnikom z rąk, ponieważ sami zgodzili się papier uważać za żelazo stali na gruncie estetyki formalistycznej” (Wat 1930b: 124).

Papier nie może się w koncepcji Wata stać prawdziwym orężem sztuki, ponieważ żadne słowo nie uobecni w sobie potęgi i władzy czynu. Skoro zaś zadaniem człowieka jest przeobrażanie świata, a celem awangardzisty i pisarza postępowego wzięcie udziału w rewolucji, musi on porzucić instrumentarium literatury pięknej, zapomnieć o swojej własnej tożsamości, zrezygnować z kreowania kolejnych, sztucznych „tekstowych ja” i zwrócić twarz ku realności, gdyż to ona pozostaje jedynym gwarantem prawdy. Pragnienie autentyzmu każe Watowi w latach trzydziestych przestać pisać, bo wszystko, co zapisane, zostaje przecież poddane autorskiej autokreacji: nie ujawnia się w tym obraz prawdziwy, gdyż takiego nie jesteśmy w stanie świadomie pochwycić. Jednocześnie, podążając śladem Mickiewicza, w okresie „Miesięcznika" Wat dokonuje swoistej krytyki indywidualności jako takiej (w późniejszym okresie zrewiduje oczywiście ten pogląd): nie liczy się człowiek jako jednostka, ale jako element sprawnie działającej maszyny społecznej. Zadaniem pisarza staje się kreowanie i diagnozowanie zachowań mas, budowanie państwa nie odbywa się bowiem wysiłkiem pojedynczych ludzi, ale

10 W artykule pojawiają się ciekawe uwagi dotyczące zależności między twórczością a ekonomiczną inflacją: Inflacja była wówczas formą widzenia rzeczy. Miernik rzeczy zatracił swoją stałość, skakał wraz ze skokami waluty. Prawo tożsamości przestało obowiązywać. Rzecz przestała być sobą. Nazajutrz już nie była tem, czem była poprzedniego dnia. Inflacja rozrywała identyczność rzeczy ze sobą. Rzecz, która w pierwszym okresie futuryzmu polskiego, ulegała wyolbrzymieniu w hyperboli metaforycznej teraz poddawała się wszelkim możliwym przemianom na wszelkie możliwe rzeczy. (Wat 1930e: 75-76) 
zorganizowanych grup. „Papierowa rewolucja” nie jest w stanie podjąć walki w ich obronie; papierowym orężem artyści nie dają rady ochronić nawet sami siebie. Ich milczenie nie może być jednak absolutne i alienujące: bunt piśmienny jest buntem przeciwko literaturze pięknej, nową formą wypowiedzi staje się zatem literatura faktu. Jej obiektywizm, montażowość, fotograficzność gwarantują, że czytelnik znajdzie się najbliżej prezentowanej rzeczy. To, co zapisane na papierze, odciśnie ślad na jego skórze.

\section{Bibliografia}

Adorno Theodor Wiesengrund (1994), Teoria estetyczna, tłum. K. Krzemieniowa, Wydawnictwo Naukowe PWN, Warszawa.

Bürger Peter (2006), Teoria awangardy, tłum. J. Kita-Huber, Wydawnictwo UJ, Kraków.

Certeau Michel de (2006), Ekonomia piśmienna, tłum. P. Biłos [w:] Teorie literatury XX wieku. Antologia, red. Burzyńska A., Markowski M.P., Znak, Kraków.

Czernik Jakub (2014), Między indywidualizmem a kolektywizmem. Jednostka i zbiorowość w literaturze romantycznej, Wydawnictwo UJ, Kraków.

Groys Boris (1992), The Total Art of Stalinism. Avant-Garde, Aesthetic Dictatorship, and Beyond, transl. Ch. Rougle, Princeton UP, Princeton - New Jersey.

Hoffmann-Piotrowska Ewa (2004), O „milczeniu” Mickiewicza Towiańczyka, „Przegląd Humanistyczny", nr 2.

Jaworski Krzysztof (2015), Kronika polskiego futuryzmu, Wydawnictwo UJK, Kielce.

Kuziak Michał (2013), Inny Mickiewicz, słowo/obraz terytoria, Gdańsk.

Mickiewicz Adam (1933), Dzieta wszystkie, t. XVI: Rozmowy z Adamem Mickiewiczem, oprac.

S. Pigoń, Warszawa.

- (1955), Dzieta, t. 12: Trybuna Ludów, Czytelnik, Warszawa.

- (1998), Literatura stowiańska. Kurs IV [w:] tegoż, Dzieta, t. XI, Czytelnik, Warszawa.

Nawarecki Aleksander (2003), Maty Mickiewicz. Studia mikrologiczne, Wydawnictwo UŚ, Katowice.

Ogtoszenie konkursu na reportaż (1930), „Miesięcznik Literacki”, nr 7.

Ong Walter J. (1992), Oralność i piśmienność. Stowo poddane technologii, tłum. J. Japola, Wydawnictwo KUL, Lublin.

Pigoń Stanisław, red. (1958), Adama Mickiewicza wspomnienia i myśli, Czytelnik, Warszawa.

Przychodniak Zbigniew (2001), Walka o rzad dusz. Studia o literaturze i polityce Wielkiej Emigracji, Wydawnictwo Naukowe UAM, Poznań.

Puchner Martin (2006), Poetry of Revolution. Marx, Manifestos, and the Avant-Gardes, Princeton UP, Princeton - Oxford. 
Rancière Jacques (2007), Estetyka jako polityka, tłum. J. Kutyła, P. Mościcki, Wydawnictwo Krytyki Politycznej, Warszawa.

Rutkowski Krzysztof (1984), Ani byto, ani jest. Szkice literackie, Czytelnik, Warszawa.

Sikora Adam (1967), Postannicy stowa. Hoene-Wronski, Towiański, Mickiewicz, Wydawnictwo Naukowe PWN, Warszawa.

Sokołowski Mikołaj (1998), Tajemnica stowa. Mickiewicz wobec oralności i piśmienności [w:] Tajemnice Mickiewicza, red. Zielińska M., Wydawnictwo IBL PAN, Warszawa.

Stawar Andrzej (1930a), Legendy Mickiewiczowskie, „Miesięcznik Literacki”, nr 4.

— (1930b), Mickiewicz, „Miesięcznik Literacki”, nr 6.

Walicki Andrzej (1970), Filozofia a mesjanizm. Studia z dziejów filozofii i myśli spoteczno-religijnej romantyzmu polskiego, PIW, Warszawa.

Wat Aleksander (1929), Pacyfistyczna literatura w Niemczech, „Miesięcznik Literacki”, nr 1.

- (1930a), Jeszcze o reportażu, „Miesięcznik Literacki”, nr 10.

- (1930b), Metamorfozy futuryzmu, „Miesięcznik Literacki”, nr 3.

- (1930c), Poeta rewolucji Majakowski, „Miesięcznik Literacki”, nr 6.

- (1930d), Reportaż jako rodzaj literacki, „Miesięcznik Literacki”, nr 7.

- (1930e), Wspomnienia of futuryzmie, „Miesięcznik Literacki”, nr 2.

- (1990), Mój wiek. Pamiętnik mówiony, t. 1, oprac. K. Rutkowski, Czytelnik, Warszawa.

- (2008), Wybór wierszy, oprac. A. Dziadek, Zakład Narodowy im. Ossolińskich, Wrocław.

Weintraub Wiktor (1998), Mickiewicz - mistyczny polityk i inne studia o poecie, IBL PAN, Warszawa.

Witkowska Alina (1975), Mickiewicz. Stowo i czyn, Wydawnictwo Naukowe PWN, Warszawa. 